\title{
COMPARATIVE ANALYSIS OF RESEARCH AND CALCULATED VALUES OF BEARING CAPACITY OF REINFORCED CONCRETE AND BASALT CONCRETE BEAMS ACCORDING TO RECOMMENDATIONS OF NATIONAL DESIGN STANDARDS
}

\author{
${ }^{1}$ Karpiuk I., Ph.D., Associate Professor, \\ irina.carpyuk@yandex.ru, ORCID: 0000-0003-3437-5882 \\ ${ }^{1}$ Karpiuk V., Ph.D., Professor, \\ v.karpiuk@ukr.net, ORCID: 0000-0002-4088-6489 \\ ${ }^{1}$ Klimenko E., Ph.D., Professor, \\ klimenkoew57@gmail.com, ORCID: 0000-0002-4502-8504 \\ ${ }^{1}$ Tselikova A., Assistant, \\ tselikovaa93@gmail.com, ORCID: 0000-0002-1394-3986 \\ ${ }^{1}$ Khudobych A., graduate student, \\ khudobycha@gmail.com, ORCID: 0000-0002-5336-599X \\ ${ }^{1}$ Odessa State Academy of Civil Engineering and Architecture \\ str. Didrichson, 4, Odessa, 65029, Ukraine
}

\begin{abstract}
Non-metal composite reinforcement is increasingly being used in modern construction. Composite reinforcement is a great step forward over steel, due to its higher strength and corrosion resistance. An analysis of the use of these fittings was performed, which showed that the United States, Japan and China are leading countries in the use of composite fittings. The more active pace of implementation of composite reinforcement is limited by the fact that composite reinforcement does not have a common method for calculating their bearing capacity. That is why the article discusses regulatory documents on the calculation and design of structures reinforced with composite reinforcement from around the world.

The article provides a comparative analysis of the calculations of the bearing capacity of prototypes - beams, reinforced with basalt-plastic reinforcement, according to the available design standards of foreign countries, which were among the first to use non-metallic composite reinforcement for reinforcing span concrete structures. The methods of calculating the bearing capacity of beam elements for concrete and non-metallic composite reinforcement according to regulatory documents are examined in detail. A comparative analysis of the actual bearing capacity of inclined sections of basalt concrete beams and its calculated values calculated according to the recommendations of the existing design standards of foreign countries is carried out.

The analysis showed that the actual bearing capacity of the inclined sections of basalt concrete beams and its calculated value showed their unsatisfactory convergence. A common feature of all considered foreign design standards is the underestimation, up to several times, of the bearing capacity of inclined sections of prototypes - beams reinforced with both steel and basaltplastic reinforcement. It has been established that the methods for calculating the bearing capacity of supporting sections of spans of reinforced concrete and basalt concrete structures, presented in national design standards, are based not on the new general method, but on partially improved methods that were used in previously existing standards.
\end{abstract}

Keywords: non-metallic composite reinforcement, foreign design standards, basalt-concrete beams, bearing capacity, recommendations, inclined sections.

Introduction. Reinforced concrete is widely used in modern construction, in which concrete and steel reinforcement work effectively. Non-metallic composite reinforcement has higher strength, better dielectric properties, low weight and does not corrode, increasingly replacing steel reinforcement, especially in special purpose buildings. Its use for the reinforcement of concrete structures is constrained by insufficient study of the features of such elements, limited regulatory support and little experience in the operation of relevant facilities. Based on this, research on the operation of structures 
reinforced with basalt-plastic reinforcement (BFRP), and the development of practical recommendations that would allow the use of such reinforcement in construction are relevant.

Analysis of recent sources of publications. Different countries of the world are engaged in the development of normative documents for the calculation and design of structures reinforced with composite reinforcement. The main normative documents, which provide methods for calculating the load-bearing capacity of concrete beam structures reinforced with NCA are: European EUROCODE - 2 [1], Japanese JSCE [2], American ACI [3], Canadian CSA [4], Italian CNR [5], DSTU-N B B.2.6-185: 2012 [6] and DSTU B. V.2.6. - 156: 2010 [7].

Purpose and tasks: to make the comparative analysis of the results of calculations of bearing capacity of inclined sections of experimental samples - the beams reinforced by BFRP; to get acquainted with the existing design standards of foreign countries, which were one of the first to use NCA for the reinforcement of reinforced concrete structures, under the action of static load; to give the formulas of the component bearing capacity for concrete and the component bearing capacity for NCA.

Materials and methods of research. The materials of the research are the obtained experimental values of the bearing capacity of inclined sections of single-girder concrete beams reinforced with BFRP, and normative documents of different countries of the world. Obtaining and comparing the calculated values of the bearing capacity of the supporting sections of the deflected basalt concrete structures according to different normative documents, and a comparative analysis with the actual bearing capacity of the prototypes.

Basic material and results. Composite reinforcement has a great advantage over steel, due to its high strength and corrosion resistance. This material is not able to be magnetized, which makes it possible to use this material in places of special equipment, such as hospitals, chemical plants and more. That is why composite reinforcement is increasingly used in construction in different countries (Fig. 1). An analysis of the use of these fittings was performed, which showed that the United States, Japan and China are leading countries in the use of composite fittings. They were the first countries to develop regulations for the design of structures reinforced with composite reinforcement.

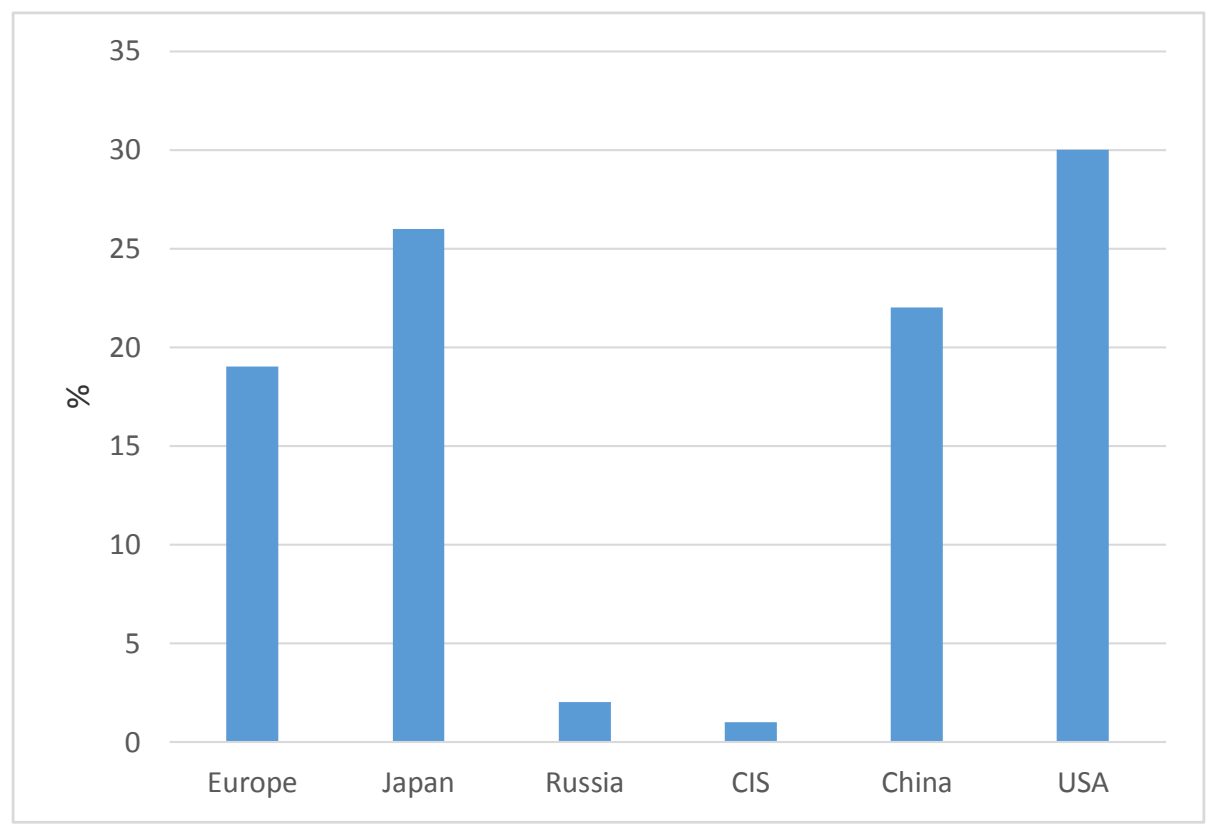

Fig. 1. The use of composite fittings in different countries

To achieve this goal in the laboratory of the Department of Reinforced Concrete Structures and Transport Structures of the Odessa State Academy of Civil Engineering and Architecture was implemented a series of field experiments with single-girder beams reinforced BFRP, under static load of high levels according to the state budget theme (№ state registration 0116U002340, 0114U000897). 
Prototypes - basalt concrete beams were reinforced with BFRP in the form of two flat knitted frames. For the manufacture of these elements were used heavy concrete classes C16/20, C30/35, C40/50 on granite crushed stone fractions of $5-10 \mathrm{~mm}$ and quartz sand with a size modulus of 1.5. Portland cement grade 500 without additives was used as a binder. To reduce the water-cement ratio, improve the ease of laying of the concrete mixture and reduce the time of accumulation of concrete strength in all experiments was used a complex additive Relaxol-Super M (ISO 9001 № 04.156.26) in the amount of $1 \%$ by weight of cement in terms of dry matter.

To test the beams, special power plants were designed, manufactured and certified (Fig. 2). The load was applied according to a four-point scheme using a hydraulic jack DG-50 and a distribution beam-traverse in two concentrated forces in steps: $(0.04 \ldots 0.06) \mathrm{F}_{\mathrm{ult}}$ before the appearance of the first normal and inclined cracks, then - by $(0.08 \ldots 0.12) F_{\text {ult }}$ to excessive opening of these cracks and again on $(0.04 \ldots 0.05) \mathrm{F}_{\text {ult }}$ up to destruction. The load endurance on the step was up to 15 minutes with all measurements at the beginning and end of each load step.

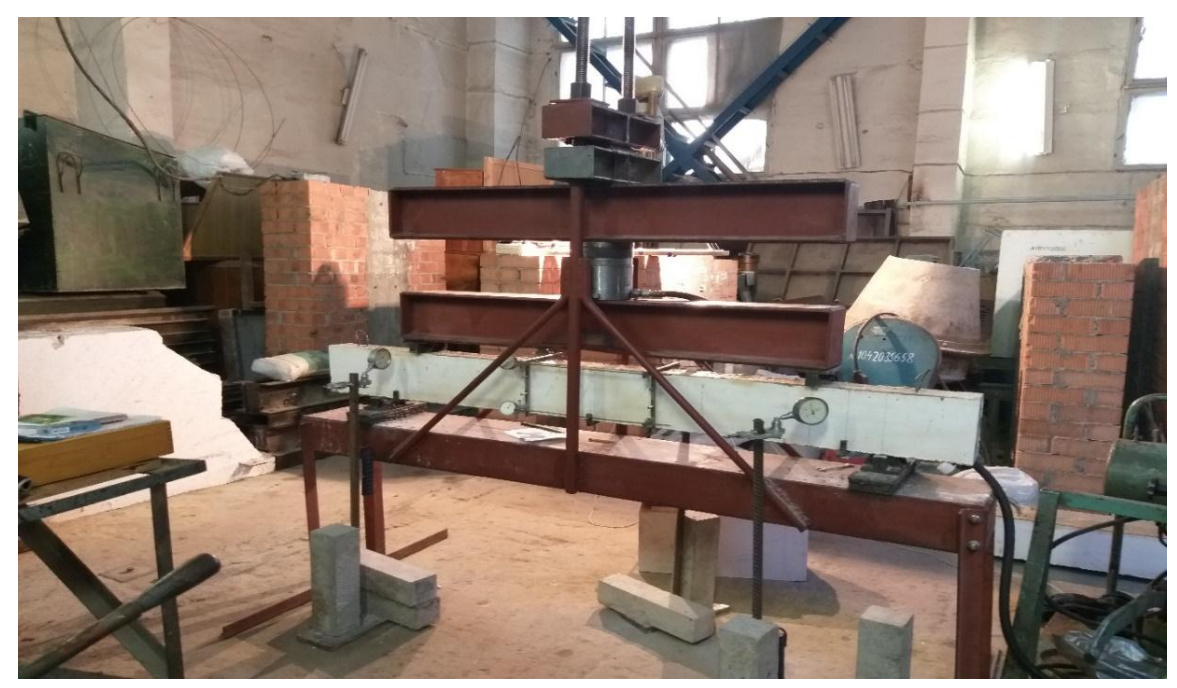

Fig. 2. Power plant

To compare the obtained experimental values of the load-bearing capacity of inclined sections of single-girder concrete beams reinforced with BFRP, the available foreign design standards were selected: European EUROCODE - 2 [1], Japanese JSCE [2], American ACI [3], Canadian CSA [4], Italian CNR [5], DSTU-N B B.2.6-185:2012 [6] and DSTU B. B.2.6. - 156:2010 [7]. Upon detailed study of these regulations, it was found that in the Japanese standards JSCE [2] the empirical formula for determining the component load-bearing capacity of concrete when calculating the transverse force is written in a form that repeats the formula for calculating the reinforced concrete element, but taking into account the area of transverse reinforcement:

$$
\mathrm{V}_{\mathrm{cd}}=2 \sqrt[4]{1 / d} \cdot \sqrt[3]{\frac{100 A_{f} \cdot E_{f}}{b_{w} \cdot d \cdot E_{s}}} \cdot \sqrt[3]{f_{c}} \cdot b_{w} \cdot d
$$

where $b_{w}$ - section width;

$\mathrm{d}$ - working height of section.

The component of bearing capacity on NCA is written taking into account the limitation of its deformations by empirical dependence:

$$
\mathrm{V}_{\mathrm{sf}}=\frac{A_{f w} \cdot E_{f w} \cdot \varepsilon_{f w d}}{s} \cdot z
$$

where $\varepsilon_{f w d}-$ the calculated limit of relative deformations of the transverse NCA, which is determined by the formula: 


$$
\varepsilon_{f w d}=\sqrt{\left(\frac{h}{0.3}\right)^{0.1} \cdot f_{c} \frac{p_{f} \cdot E_{f}}{p_{f w} \cdot E_{f w}}} \cdot 10^{-4},
$$

in which $p_{f w}$ - the coefficient of transverse reinforcement of the beam;

$\mathrm{z}$ - shoulder of the inner pair of forces, $\mathrm{z}=0.9 \mathrm{~d}=0.9 \mathrm{~h}_{0}$;

$\mathrm{s}-$ step of transverse reinforcement.

Based on the same principle, European standards Eurocode - 2 [1] propose to determine the component of the transverse force on concrete by the formula:

$$
V_{c f}=0.12\left(1+\sqrt{\frac{200}{d}}\right) \cdot\left(100 \frac{A_{f} \cdot E_{f}}{b_{w} \cdot d \cdot E_{s}} \varphi_{\varepsilon} \cdot f_{c k}\right)^{1 / 3} \cdot b_{w} \cdot d,
$$

where the coefficient $\varphi_{\varepsilon}=\frac{\varepsilon_{f}}{\varepsilon_{y}}, \varepsilon_{f}=0.0045$, as an experimentally established value.

The component of bearing capacity of cross section on NCA in these norms is defined taking into account restriction of its deformations by size of $0.25 \%$ :

$$
V_{s f}=\frac{A_{f w} \cdot f_{f w} \cdot d}{s}
$$

where $f_{f w}=E_{f w} \cdot 0.0025$.

In the American norms of ACI [3] at definition of a component of bearing capacity of an inclined section on concrete is the same model, as for a reinforced concrete element, with application of coefficient $12 \mathrm{k} / 5$ :

$$
V_{c f}=(12 k / 5) \cdot 0.167 \sqrt{f_{c}} \cdot b_{w} \cdot d,
$$

where $k=\sqrt{p_{f} \cdot n_{f} \cdot 2+\left(p_{f} n_{f}\right)^{2}}-p_{f} \cdot n_{f} ; p_{f}=\frac{A_{f}}{b_{w} d} ; n_{f}=\frac{E_{f}}{E_{c}}$.

The component of bearing capacity of an inclined section on NCA in them is defined as for steel armature, but with restriction of its deformations of $0.40 \%$ and restriction of durability for NCA with bends:

$$
V_{s f}=\frac{A_{f w} \cdot f_{f w} \cdot d}{s}
$$

where $f_{f w}=0.004 E_{f} \leq f_{f b} ;$

$f_{f b}$ - the calculated strength of the transverse reinforcement with bends or clamps. Usually $f_{f b}=0.5-0.6 f_{u}$.

In the Canadian standards of CSA [4] the component of bearing capacity on concrete is accepted without change concerning formulas for reinforced concrete elements:

$$
V_{c g}=1.3 \cdot \lambda \cdot \beta \cdot \sqrt{f_{c}{ }^{\prime}} \cdot b_{w} \cdot d_{v}
$$

where $\lambda=1$ for heavy concrete;

$\beta=0.167$ - coefficient that takes into account the shear resistance of inclined sections with diagonal cracks;

$d_{u}=0.9 d-$ shoulder of a pair of internal forces;

$f_{c}^{\prime}$ - characteristic resistance of concrete to compression (peak point of the calculated deformation diagram).

The component of bearing capacity of inclined sections of basalt-concrete beams on NKA in these norms is accepted taking into account talc of $40 \%$ of strength of NCA:

$$
V_{s f}=\frac{0.4 \cdot A_{f w} \cdot f_{f w} \cdot d}{s}
$$


The Italian CNR standards [5] use formulas from the Eurocode 2 methodology until it was amended in 2004. In this case, the load-bearing capacity component of the concrete varies in proportion to the rigidity of the NCA:

$$
V_{c f}=1.3\left(\frac{E_{f}}{E_{s}}\right)^{0.5} \cdot \tau_{R d} \cdot k\left(1.2+40 p_{f}\right) b_{w} d,
$$

where $\tau_{R d}=0.25 f_{\text {ctd }}$ - the calculated value of shear strength of concrete;

$f_{c t d}-$ design tensile strength of concrete;

$k$ - coefficient equal to 1 , if more than $50 \%$ of the lower working reinforcement of the bending element is not brought to the support and $k=1.6-$ if all the longitudinal reinforcement is accounted for. The load-bearing capacity component of the NCA in CNR [5] is determined taking into account the coefficient of operating conditions of the transverse reinforcement of 0.5 :

$$
V_{R d, f}=\frac{A_{f w} \cdot f_{f r} \cdot d}{s}=\frac{0.5 \cdot f_{f e} \cdot A_{f w} \cdot d}{s} .
$$

In domestic norms [6, 7] and many author's methods, only general information without specifics is given. The analysis of the obtained results shows that the previously operating domestic SNiP 2.03.01 $-84 *$ have a much better convergence (coefficient of variation $v=17.5 \%$ ) of the calculated and experimental data of the bearing capacity of reinforced concrete beams compared to the current in Ukraine Eurocode 2 [1] in the form DSTU B. B.2.6. - 156: 2010 [7] $(v=65.4 \%)$ because they better than European and other foreign standards reflect the physical picture of the work of experimental beams under load. However, in experiments with large shear spans $\left(\mathrm{a} / \mathrm{h}_{0}=3\right)$ and the maximum amount of transverse reinforcement $\left(\mathrm{p}_{\mathrm{sw}}=0.0044\right)$, the load-bearing capacity of inclined sections of reinforced concrete beams predicted by SNiP [8] exceeds their actual strength on average by $28 \%$ that is dangerous.

Comparison of the actual bearing capacity of inclined sections of basalt concrete beams and its calculated values, calculated according to the recommendations of the existing design standards of foreign countries, showed unsatisfactory, in general, their convergence. Thus, the coefficients of variation according to Eurocode 2 [1] $v=85.2 \%$; JSCE [2] $v=77.9 \%$; ACI [3] $v=81.7 \%$; CSA [4] $v=61.1 \%$; CNR [5] $v=59.0 \%$. Calculations have shown that European Eurocode 2 [1], Japanese JSCE [2] and American ACI [3] standards significantly underestimate the load-bearing capacity of inclined sections of experimental concrete beams reinforced with BFRP. Canadian CSA A [4] and Italian CNR [5] regulations significantly (up to 2 times) exceed the bearing capacity of basalt concrete beams with long spans $\left(\mathrm{a} / \mathrm{h}_{0}=3\right)$, which can create an emergency situation on real objects.

A common feature of all considered foreign design standards is the underestimation of the bearing capacity of inclined sections of prototypes - beams reinforced with both steel and basaltplastic reinforcement up to several times.

Conclusions. Analysis of methods for calculating the bearing capacity of the supporting sections of reinforced concrete and basalt-concrete structures presented in national design standards, as well as author's methods showed that the vast majority of them are not based on a new general method, but on partially improved methods used in the previously existing standards. In particular, the calculation methods of Eurocode 2 [1] and other foreign countries are based on various conditional schemes and analogies, which require the application of an empirical approach and the use of an increasing number of formulas of the same origin. In this case, for a large number of prototypes - beams with large spans of the section $\left(\mathrm{a} / \mathrm{h}_{0}=3\right)$ there was insufficient reliability of the calculation formulas, because the calculated strength of their inclined sections significantly exceeded the actual load-bearing capacity of these sections.

Thus, the comparison of experimental and calculated values of bearing capacity of inclined sections of experimental reinforced concrete and basalt concrete elements, calculated according to the recommendations of these national design standards, showed that the best convergence of these values is characteristic of those standards that are not based on modified truss analogy or modified, and on those calculation schemes which better reflect a physical picture of their work under loading.

Bulletin of Odessa State Academy of Civil Engineering and Architecture, 2020, no. 80, page 43-49 


\title{
References
}

[1] EN 1992-1-1:2004, Eurocode 2 - Design of Concrete Structures. Part 1: General rules and rules, CEN, 2004.

[2] JSCE, Recommendation for Design and Construction of Concrete Structures Using Continuous Fiber Reinforcing Materials. Tokyo, Japan: Japan Society of Civil Engineers, 1997.

[3] ACI 440.1R-03, Guide for the Design and Construction of Concrete Reinforced with FRP Bars, American Concrete Institute, 2003.

[4] CAN/CSA-S6-00, Canadian High Bridge Design Code, Canadian Standards Association, 2019.

[5] CNR-DT 203/2006, Guide for the Design and Construction of Concrete Structures Reinforced with Fiber-Reinforced Polymer Bars, Rome, Italy, 2006.

[6] DSTU-N B V.2.6-185:2012. Nastanova $\mathrm{z}$ proektuvanjya ta vigotovlenja betonnjih konstrukcij z nemetalevoju kompozitivnoju armaturoju na osnovi bazalto- I sklo- rovingu: Kiev, Minregionbud, 2012.

[7] DSTU B V.2.6-145:2010. Konstrukciji budinkiv I sporud. Zahist betonnih I zalizobetonnih konstrukcij vid koroziji. Zahalni tehnichni vimogy. Ukrajina, 2010.

[8] SNiP 2.23.01-84*. Betonniyi I zhelezobetonniyi konstrukciji. Gosstroy SSSR. M. CITP Gosstroya SSSR, 1989.

\section{ПОРІВНЯЛЬНИЙ АНАЛІЗ ДОСЛІДНИХ І РОЗРАХУНКОВИХ ЗНАЧЕНЬ НЕСУЧОЇ ЗДАТНОСТІ ЗАЛІЗОБЕТОННИХ І БАЗАЛЬТОБЕТОННИХ БАЛОК ЗА РЕКОМЕНДАЦІЯМИ НАЦІОНАЛЬНИХ НОРМ ПРОЕКТУВАННЯ}

\author{
${ }^{1}$ Карпюк І.А., к.т.Н., доцент, \\ irina.carpyuk@yandex.ru, ORCID: 0000-0003-3437-5882 \\ ${ }^{1}$ Карпюк В.M., д.т.н., професор, \\ v.karpiuk@ukr.net, ORCID: 0000-0002-4088-6489 \\ ${ }^{1}$ Клименко Є.B., д.Т.н., професор, \\ klimenkoew57@gmail.com, ORCID: 0000-0002-4502-8504 \\ ${ }^{1}$ Целікова А.С., асистент, \\ tselikovaa93@gmail.com, ORCID: 0000-0002-1394-3986 \\ ${ }^{1}$ Худобич А.O., аспірант, \\ khudobycha@gmail.com, ORCID: 0000-0002-5336-599X \\ ${ }^{1}$ Одеська державна академія будівництва та архітектури \\ вул. Дідріхсона, 4, м. Одеса, 65029, Україна
}

Анотація. Все частіше в сучасному будівництві застосовується неметалева композитна арматура. Неметалева композитна арматура має більш високу міцність, кращі діелектричні властивості, малу вагу та не піддається корозії, саме тому вона все частіше замінює сталеву арматуру. Більш активні темпи впровадження композитної арматури обмежені тим, що композитна арматура не має загального методу розрахунку їі несучої здатності. Саме тому в статті розглядаються нормативні документи 3 розрахунку i проектування конструкцій, армованих композитною арматурою, різних країн світу.

У статті наводиться порівняльний аналіз розрахунків несучої здатності дослідних зразків - балок, армованих базальтопластиковою арматурою, за наявними нормами проектування зарубіжних країн, які одні з перших почали застосовувати неметалеву композитну арматуру для армування прогінних бетонних конструкцій. Детально розглядається методика розрахунку несучої здатності балкових елементів по бетону і неметалевій композитній арматурі, згідно нормативних документів. Зроблено порівняльний аналіз фактичної несучої здатності похилих перерізів базальтобетонних балок і розрахункових їх значень, обчислених за рекомендаціями наявних норм проектування зарубіжних країн.

Аналіз показав, що фактична несуча здатність похилих перерізів базальтобетонних балок і розрахункове iї значення, показало незадовільну їх збіжність. Спільною рисою всіх розглянутих 
зарубіжних норм проектування є недооцінка, до декількох разів, несучої здатності похилих перерізів дослідних зразків - балок, армованих як сталевою, так і базальтопластиковою арматурою. Встановлено, що методи розрахунку несучої здатності приопорних ділянок прогінних залізобетонних і базальтобетонних конструкцій, які закладені в національних нормах проектування, базуються не на новому загальному методі, а на частково вдосконалених методиках, які використовувалися свого часу в раніше діючих нормах.

Ключові слова: неметалева композитна арматура, зарубіжні норми проектування, базальтобетоні балки, несуча здатність, рекомендації, похилі перерізи.

\title{
СРАВНИТЕЛЬНЫЙ АНАЛИЗ ИССЛЕДОВАТЕЛЬСКИХ И РАСЧЕТНЫХ ЗНАЧЕНИЙ НЕСУЩЕЙ СПОСОБНОСТИ ЖЕЛЕЗОБЕТОННЫХ И БАЗАЛЬТОБЕТОННЫХ БАЛОК ПО РЕКОМЕНДАЦИЯМ НАЦИОНАЛЬНЫХ НОРМ ПРОЕКТИРОВАНИЯ
}

\author{
${ }^{1}$ Карпюк И.А., к.т.Н., доцент, \\ irina.carpyuk@yandex.ru, ORCID: 0000-0003-3437-5882 \\ ${ }^{1}$ Карпюк В.M., д.т.н., профессор, \\ v.karpiuk@ukr.net, ORCID: 0000-0002-4088-6489 \\ ${ }^{1}$ Клименко Е.В., д.т.Н., профессор, \\ klimenkoew57@gmail.com, ORCID: 0000-0002-4502-8504 \\ ${ }^{1}$ Целикова А.С., ассистент, \\ tselikovaa93@gmail.com, ORCID: 0000-0002-1394-3986 \\ ${ }^{1}$ Худобич А.А., аспирант, \\ khudobycha@gmail.com, ORCID: 0000-0002-5336-599X \\ ${ }^{1}$ Одесская государственная академия строительства и архитектуры \\ ул. Дидрихсона, 4, г. Одеса, 65029, Украина
}

Аннотация. Все чаще в современном строительстве применяется неметаллическая композитная арматура. Более активные темпы внедрения композитной арматуры ограничены тем, что композитная арматура не имеет общего метода расчета ее несущей способности. Именно поэтому в статье рассматриваются нормативные документы по расчету и проектированию конструкций, армированных композитной арматурой, разных стран мира.

В статье приводится сравнительный анализ расчетов несущей способности опытных образцов - балок, армированных базальтопластиковой арматурой, по имеющимся нормам проектирования зарубежных стран, которые одни из первых начали применять неметаллическую композитную арматуру для армирования пролетных бетонных конструкций. Подробно рассматривается методика расчета несущей способности балочных элементов по бетону и неметаллической композитной арматуры, согласно нормативных документов. Произведен сравнительный анализ фактической несущей способности наклонных сечений базальтобетонных балок и расчетных ее значений, вычисленных по рекомендациям имеющихся норм проектирования зарубежных стран.

Анализ показал, что фактическая несущая способность наклонных сечений базальтобетонных балок и расчетное ее значение, показало неудовлетворительную их сходимость. Общей чертой всех рассмотренных зарубежных норм проектирования является недооценка, до нескольких раз, несущей способности наклонных сечений опытных образцов - балок, армированных как стальной, так и базальтопластиковой арматурой. Установлено, что методы расчета несущей способности приопорных участков пролетных железобетонных и базальтобетонных конструкций, заложенные в национальных нормах проектирования, базируются не на новом общем методе, а на частично усовершенствованных методиках, которые использовались в свое время в ранее действующих нормах.

Ключевые слова: неметаллическая композитная арматура, зарубежные нормы проектирования, базальтобетонные балки, несущая способность, рекомендации, наклонные сечения.

Стаття надійшла до редакції 20.06.2020

Bulletin of Odessa State Academy of Civil Engineering and Architecture, 2020, no. 80, page 43-49 